\title{
Contextual Effect of the Integrated Non-Communicable Disease Health Post on the Performance of Community Health Workers: A Multilevel Analysis Evidence from Karanganyar, Central Java
}

\author{
Eka Siti Chasanah'), Endang Sutisna Sulaeman²), Setyo Sri Rahardjo²) \\ 1)Masters Program in Public Health, Universitas Sebelas Maret \\ 2)Faculty of Medicine, Universitas Sebelas Maret
}

\section{ABSTRACT}

Background: Epidemiological transition is causing a shift from Communicable to NonCommunicable Diseases (NCD). NCD is a serious threat because it impacts decreasing productivity and increasing economic and social burdens for the community. The control of NCD risk factors in Indonesia is carried out by empowering the community through the Integrated Non-Communicable Diseases Health Post (Posbindu NCD). One of the important factors determining the success of implementing Posbindu is the role of cadres. This study aims to analyze the factors that affect the performance of Posbindu cadres.

Subjects and Method: This was an analytic observational study with a cross-sectional design. The study was conducted in 25 posbindus in Karanganyar, Central Java, from February to April 2020. A sample of 200 cadres from 25 cadres was selected by stratified random sampling. The dependent variable was the performance of the Posbindu cadres. The independent variables were training, ability, length of employment, motivation, the leadership of the Posbindu chairman, social network support and appreciation. Data were analyzed using multilevel logistic regression with Stata 13.

Results: Job performance increased with training $(b=1.75 ; 95 \% \mathrm{CI}=0.28$ to $3.22 ; \mathrm{p}=0.019)$, good ability $(\mathrm{b}=2.50 ; 95 \% \mathrm{CI}=0.95$ to $4.04 ; \mathrm{p}=$ 0.002), tenure $\geq 1$ year ( $b=1.99 ; 95 \% \mathrm{CI}=0.05$ to $3.92 ; \mathrm{p}=0.044)$, strong motivation $(\mathrm{b}=2.57 ; 95 \%$ $\mathrm{CI}=1.25$ to $3.89 ; \mathrm{p}<0.001$ ), good leadership of Posbindu chairman $(b=1.73 ; 95 \% \mathrm{CI}=0.44$ to 3.03; $\mathrm{p}=0.009$ ), and strong social network support $(b=1.24 ; 95 \% \mathrm{CI}=0.14$ to $2.34 ; \mathrm{p}=$ o.028). Incentive increased job performance, but it was statistically non-significant $(b=1.19 ; 95 \%$ $\mathrm{CI}=-0.35$ to $2.73 ; \mathrm{p}=0.132)$. Posbindu had a strong contextual effect on job performance with an ICC of $62.73 \%$.

Conclusion: Job performance increases with training, good abilities, tenure $\geq 1$ year, strong motivation, good leadership of Posbindu chairman, strong social network support, and appropriate incentives. Posbindu has a strong contextual effect on job performance.

Keywords: performance, cadre, non-communicable disease

\section{Correspondence:}

Eka Siti Chasanah. Masters Program in Public Health, Universitas Sebelas Maret. Jl. Ir. Sutami 36A, Surakarta 57126, Central Java. Email: ekasc12@gmail.com. Mobile: +6281329017587.

\section{Cite this as:}

Chasanah ES, Sulaeman ES, Rahardjo SS (2020). Contextual Effect of the Integrated Non-Communicable Disease Health Post on the Performance of Community Health Workers: A Multilevel Analysis Evidence from Karanganyar, Central Java. J Health Policy Manage. 05(03): 204-216. https://doi.org/10.26911/thejhpm.2020.05.03.06.

Journal of Health Policy and Management is licensed under a Creative Commons Attribution-NonCommercial-ShareAlike 4.o International License.

\section{BACKGROUND}

Non-Communicable Diseases (NCD) is the cause of death for 41 million people every year or equivalent to $71 \%$ of deaths worldwide, 32 million (78\%) of which occur in low- and middle-income countries (WHO, 2018). Indonesia is currently facing an epidemiological transition that has led to a shift in disease from infectious diseases to NCD (Ministry of Health, 2019). The prevalence of 
NCD based on the results of the Basic Health Research (Riskesdas) in 2018 has increased compared to the 2013 Riskesdas. The prevalence of cancer increased from $1.4 \%$ to $1.8 \%$, chronic kidney disease from $2 \%$ to $3.8 \%$, and stroke prevalence from $7 \%$ to $10.9 \%$. Based on the examination of blood sugar, diabetes rose from $6.9 \%$ to $8.5 \%$. From the blood pressure measurements, hypertension rose from 25.8\% to $34.1 \%$ (Ministry of Health, 2019).

Increased morbidity and mortality due to NCD is a serious threat because it impacts the economic and social burden on the community (Ministry of Health, 2014).

NCD's macroeconomic impact is very large because it causes loss of productivity and a decrease in Gross Domestic Product (Kundu et al., 2018). In Indonesia, NCD risk factor control is carried out by engaging community participation through the Integrated Development Post (Posbindu) (Ministry of Health, 2014). One of the important factors determining the success of implementing Posbindu is the role of cadres. Posbindu cadres are at the forefront of change agents in preventing and controlling NCD (Ministry of Health, 2019). Fuadah (2018) stated that cadres' participation is needed to further socialize Posbindu to the community. This is in accordance with a study conducted by Sari and Savitri (2018), which stated that cadres' role is the most dominant factor in the use of Posbindu. Rusdiyanti (2018) concluded that cadres' role has the greatest effect on the activeness of community visits to Posbindu. Jeet et al. (2017) stated that cadres' role in health can be effective in developing countries, especially in controlling smoking behavior, blood pressure, and diabetes.

The performance of Posbindu cadres has a strategic function because Posbindu agendasdepend on the role of cadres in carrying out their duties and obligations. The Posbindu cadres' performance is important to research to optimize the implementation and use of Posbindu by the community.

\section{SUBJECTS AND METHOD}

\section{Study Design}

This was an analytic observational study with a cross-sectional design. The study was conducted at 25 Posbindu, Karanganyar, Central Java, from February to April 2020.

\section{Populationand Sample}

The population was all Posbindu cadres in the Karanganyar Regency, Central Java. A sample of 200 cadres was selected by stratified random sampling.

\section{Study Variables}

This study's variables included the dependent variable and independent variables. The dependent variable was job performance of Posbindu cadres and the independent variables were training, ability, length of employment, motivation, the leadership of the Posbindu chairman, social network support, and rewards.

\section{Operational Definition of Variables} Job performance was the work of Posbindu cadres in doing their jobs. Data collection usedwas a questionnaire. The measurement scale was continuous, but for analysis, the data was converted into a dichotomy.

Training was an activity to improve the knowledge and technical skills of Posbindu cadres. Data collection used a questionnaire. The measurement scale was continuous, but for analysis, the data was converted into a dichotomy.

Ability was the Posbindu cadres' ability to measure NCD risk factors, including measuring height, abdominal circumference, body fat, and checking blood pressure. Data collection used a questionnaire. The measurement scale was continuous, but for analysis, the data was converted into a dichotomy.

Length of employment was a period as a Posbindu cadre, stated in years. Data were collected using a questionnaire. The mea- 
surement scale was continuous, but for analysis, the data was converted into a dichotomy.

The motivationwas a work motivation that arises in cadres to provide services in Posbindu. Data were collected using a questionnaire. The measurement scale was continuous, but for analysis, the data was converted into a dichotomy.

Appreciationwas a reward/remuneration given to cadres for their performance. Data were collected using a questionnaire. The measurement scale was continuous, but for analysis, the data was converted into a dichotomy.

Leadershipwas the leader (chairman of Posbindu) to regulate and manage cadres (members) to carry out the assigned tasks and responsibilities. Data were collected using a questionnaire. The measurement scale was continuous, but for analysis, the data was converted into a dichotomy.

Social network support provided encouragement, enthusiasm, or attention from community leaders and stakeholders to Posbindu activities. Data were collected using a questionnaire. The measurement scale was continuous, but for analysis, the data was converted into a dichotomy.

\begin{tabular}{lccccc}
\hline Variable & (n) & Mean & SD & Minimal & Maximal \\
\hline Age (year) & 200 & 41.69 & 10.61 & 16 & 67 \\
Length of employment (year) & 200 & 3.01 & 2.57 & 0.25 & 11 \\
Training & 200 & 1.77 & 0.56 & 0 & 2 \\
Motivation & 200 & 13.59 & 3.22 & 4 & 18 \\
Appreciation & 200 & 1.17 & 1.02 & 0 & 4 \\
Posbindu chairman's leadership & 200 & 17.09 & 1.46 & 9 & 18 \\
Social network support & 200 & 5.53 & 1.49 & 3 & 8 \\
Ability & 200 & 24.14 & 3.00 & 13 & 26 \\
Performance & 200 & 36.66 & 2.06 & 30 & 38 \\
\hline
\end{tabular}

Table 2 shows that as many as 111 cadres (55.50\%) were in the age $\geq 40$ years, 151 cadres $(75.50 \%)$ were highly educated ( $\geq$ Senior Hich School), 73 cadres (36.50\%) worked outside the home, as many as 168

\section{Data Analysis}

Univariate analysis was used to describe each variable. Continuous data were presented with mean, standard deviation, minimum and maximum values, while categorical data were presented as percentages. The bivariate analysis described the effect of one independent variable on one dependent variable. Meanwhile, multivariate analysis explained the effect of more than one independent variable on the dependent variable. The method used was multilevel multiple logistic regression with the STATA 13 program.

\section{Research Ethic}

This research was conducted with due observance of the basic principles of research ethics and has obtained ethical feasibility from the Health Research Ethics Commission of Dr. Moewardi Surakarta with Number: 326/II/HREC/2020 in February 17, 2020.

\section{RESULTS}

\section{Sample Characteristics}

This study involved 200 cadres from 25 Posbindu in Karanganyar Regency. The study subjects had an average age of 41.69 years, with an average length of employment of 3.01 years. The characteristics of the continuous and categorical data samples are described in Tables 1 and 2.

cadres (84.00\%) had attended training Posbindu, 145 cadres (72.50\%) had good abilities, 172 cadres (86.00\%) with a length of employment $\geq 1$ year,138 cadres (69.00\%) had strong motivation, 126 cadres (63.00\%) 
received good appreciation, 125 cadres (62.50\%) with good leadership of Posbindu chairman, 109 cadres (54.50\%)thought that
Posbindu had good socialnetwork support. As many as 121 cadres (60.50\%) had a good performance.

Tabel 2. Characteristics of categorical data samples

\begin{tabular}{|c|c|c|}
\hline Characteristics & $\mathbf{n}$ & $\%$ \\
\hline \multicolumn{3}{|l|}{ Age } \\
\hline a. $<40$ years & 89 & 44.50 \\
\hline b. $\geq 40$ years & 111 & $55 \cdot 50$ \\
\hline \multicolumn{3}{|l|}{ Education } \\
\hline a. Low (< Senior High School) & 49 & 24.50 \\
\hline b. High ( $\geq$ Senior High School) & 151 & $75 \cdot 50$ \\
\hline \multicolumn{3}{|l|}{ Occupation } \\
\hline a. Inside a house & 127 & 63.50 \\
\hline b. Outside a house & 73 & 36.50 \\
\hline \multicolumn{3}{|l|}{ Training } \\
\hline No & 32 & 16.00 \\
\hline Yes & 168 & 84.00 \\
\hline \multicolumn{3}{|l|}{ Ability } \\
\hline Poor & 55 & 27.50 \\
\hline Good & 145 & 72.50 \\
\hline \multicolumn{3}{|l|}{ Length of employment } \\
\hline$<1$ year & 28 & 14.00 \\
\hline$\geq 1$ year & 172 & 86.00 \\
\hline \multicolumn{3}{|l|}{ Motivation } \\
\hline Weak & 62 & 31.00 \\
\hline Strong & 138 & 69.00 \\
\hline \multicolumn{3}{|l|}{ Appreciation } \\
\hline Poor & 74 & 37.00 \\
\hline Good & 126 & 63.00 \\
\hline \multicolumn{3}{|c|}{ Posbindu Chairman's Leadership } \\
\hline Poor & 75 & 37.50 \\
\hline Good & 125 & 62.50 \\
\hline \multicolumn{3}{|l|}{ Social Network Support } \\
\hline Weak & 91 & $45 \cdot 50$ \\
\hline Strong & 109 & 54.50 \\
\hline \multicolumn{3}{|l|}{ Performance } \\
\hline Weak & 79 & 39.50 \\
\hline Strong & 121 & 60.50 \\
\hline
\end{tabular}

\section{The result of bivariate analysis}

The bivariate analysis results showed that cadres who had attended Posbindu training had 2.25 times the possibility of performing well compared to cadres who had never attended Posbindu training $(\mathrm{OR}=2.25 ; 95 \%$ $\mathrm{CI}=0.98$ to $5.26 ; \mathrm{p}=0.034)$. Cadres with good abilities were 8.25 times more likely to perform well than cadres with less ability $(\mathrm{OR}=8.25 ; 95 \% \mathrm{CI}=3.85$ to $18.09 ; \mathrm{p}$
$<$ o.001). Cadres who have worked $\geq 1$ year have a probability of performing well 3.94 times than cadres with a length of employment $<1$ year $(\mathrm{OR}=3.94 ; 95 \% \mathrm{CI}=1.57$ to 10.46; $\mathrm{p}=0.001)$. Cadres with strong motivation likely to have good performance 5.73 times compared to cadres with weak motivation $(\mathrm{OR}=5.73 ; 95 \% \mathrm{CI}=2.85$ to $11.64 ; \mathrm{p}$ $<0.001)$. Cadres who get good appreciation have the possibility to perform well 1.83 
times compared to cadres with less appreciation $(\mathrm{OR}=1.83$; $95 \% \mathrm{CI}=0.98$ to $3.42 ; \mathrm{p}=$ o.043). Cadres with good leadership from the Posbindu chairman have a probability of performing well 3.32 times than cadres with poor leadership of Posbindu chairman $(\mathrm{OR}=$
3.32; 95\% CI= 1.74 to $6.32 ; \mathrm{p}<0.001)$. Cadres with strong social network support were likely to perform well 3.69 times than cadres with weak social network support $(\mathrm{OR}=3.69$; 95\% CI= 1.95 to 7.01 ; $\mathrm{p}<0.001)$.

Table 3. The results of the bivariate analysis of the determinants of the performance of Posbindu cadres in Karanganyar Regency

\begin{tabular}{|c|c|c|c|c|c|c|c|c|}
\hline \multirow{3}{*}{$\begin{array}{l}\text { Independent } \\
\text { Variable }\end{array}$} & \multicolumn{4}{|c|}{$\begin{array}{c}\text { Posbindu cadres job } \\
\text { performance }\end{array}$} & \multicolumn{3}{|c|}{$95 \%$ CI } & \multirow{3}{*}{$\mathbf{p}$} \\
\hline & \multicolumn{2}{|c|}{ Poor } & \multicolumn{2}{|c|}{ Good } & \multirow[t]{2}{*}{ OR } & \multirow{2}{*}{$\begin{array}{l}\text { Lower } \\
\text { limit }\end{array}$} & \multirow{2}{*}{$\begin{array}{l}\text { Upper } \\
\text { limit }\end{array}$} & \\
\hline & $\mathbf{n}$ & \% & $\mathbf{n}$ & $\%$ & & & & \\
\hline \multicolumn{9}{|l|}{ Training } \\
\hline Never & 18 & 56.25 & 14 & $43 \cdot 75$ & \multirow{3}{*}{2.25} & \multirow{3}{*}{0.98} & \multirow{3}{*}{5.26} & \multirow{3}{*}{0.034} \\
\hline Ever & 61 & 36.31 & 107 & 63.69 & & & & \\
\hline Ability & & & & & & & & \\
\hline Poor & 41 & 74.55 & 14 & 25.45 & \multirow{3}{*}{8.25} & \multirow{3}{*}{3.85} & \multirow{3}{*}{18.09} & \multirow{3}{*}{$<0.001$} \\
\hline Good & 38 & 26.21 & 107 & 73.79 & & & & \\
\hline Tenure & & & & & & & & \\
\hline$<1$ year & 19 & 67.86 & 9 & 32.14 & \multirow{2}{*}{3.94} & \multirow{2}{*}{1.57} & \multirow{2}{*}{10.46} & \multirow{2}{*}{0.001} \\
\hline $\begin{array}{l}\geq 1 \text { year } \\
\text { Motivation }\end{array}$ & 60 & 34.88 & 112 & 65.12 & & & & \\
\hline Weak & 42 & 67.74 & 20 & 32.26 & \multirow{3}{*}{5.73} & \multirow{3}{*}{2.85} & \multirow{3}{*}{11.64} & \multirow{3}{*}{$<0.001$} \\
\hline Strong & 37 & 26.81 & 101 & 73.19 & & & & \\
\hline Appreciation & & & & & & & & \\
\hline Poor & 36 & 48.65 & 38 & 51.35 & \multirow{3}{*}{1.83} & \multirow{3}{*}{0.98} & \multirow{3}{*}{$3 \cdot 42$} & \multirow{3}{*}{0.043} \\
\hline Good & 43 & 34.13 & 83 & 65.87 & & & & \\
\hline Leadership & & & & & & & & \\
\hline Poor & 43 & $57 \cdot 33$ & 32 & 42.67 & \multirow{3}{*}{$3 \cdot 32$} & \multirow{3}{*}{1.74} & \multirow{3}{*}{6.32} & $<0.001$ \\
\hline Good & 36 & 28.80 & 89 & 71.20 & & & & \\
\hline Social Support & & & & & & & & \\
\hline Weak & 51 & 56.04 & 40 & 43.96 & 3.69 & 1.95 & 7.01 & $<0.001$ \\
\hline Strong & 28 & 25.69 & 81 & 74.31 & & & & 0.001 \\
\hline
\end{tabular}

\section{The result of multivariate analysis}

The multivariate analysis results showed that cadres who had attended the Posbindu training had a logodd (probability) to perform well 1.75 units higher than cadres who had never attended the training $(b=1.75$; 95\% CI= 0.28 to 3.22; $\mathrm{p}=0.019)$. Cadres with good abilities had a logodd (probability) to perform well 2.50 units higher than cadres with less ability $(b=2.50 ; 95 \% \mathrm{CI}=0.95$ to $4.04 ; \mathrm{p}=0.002)$. Cadres with length of employment $\geq 1$ year had a logodd (probability) to perform well 1.99 units higher than cadres with length of employment $<1$ year $(b=1.99$; $95 \% \mathrm{CI}=0.05$ to $3.92 ; \mathrm{p}=0.044)$. Cadres with strong motivation had a logodd (probability) to perform well 2.57 units higher than cadres with weak motivation $(b=2.57$; 95\% CI=1.25 to 3.89; $\mathrm{p}<0.001$ ). Cadres with good appreciation have logodd (possibility) to perform well 1.19 units higher than cadres with less appreciation. However, it was not statistically significant $(b=1.19 ; 95 \% \mathrm{CI}=$ 0.35 to $2.73 ; \mathrm{p}=0.132$ ). Cadres with good leadership of Posbindu chairman have logodd (probability) to perform well 1.73 units higher than cadres with poor leadership of Posbindu chairman $(b=1.73 ; 95 \% \mathrm{CI}=0.44$ to $3.03 ; \mathrm{p}=0.009$ ). Cadres with strong social network support had logodd (probability) to 
perform well 1.24 units higher than cadres with weak social network support ( $b=1.24$; 95\% CI $=0.14$ to $2.34 ; \mathrm{p}=0.028$ ). Posbindu had a strong contextual effect on cadre per- formance, with an ICC value of $62.73 \%$. This meant that the cadres' performance variation was $62.73 \%$, determined by the variables at the Posbindu level.

Table 4. The results of multilevel logistic regression analysis of the performance of Posbindu cadres determinants in Karanganyar Regency

\begin{tabular}{lcccc}
\hline \multicolumn{1}{c}{ Independent Variables } & b & \multicolumn{2}{c}{ 95\% CI } & p \\
& & $\begin{array}{c}\text { Lower } \\
\text { limit }\end{array}$ & $\begin{array}{c}\text { Upper } \\
\text { limit }\end{array}$ & \\
\hline Fixed effect & & & & \\
Training (have attended) & 1.75 & 0.28 & 3.22 & 0.019 \\
Ability (good) & 2.50 & 0.95 & 4.04 & 0.002 \\
Length of Employment ( $\geq$ 1 year) & 1.99 & 0.05 & 3.92 & 0.044 \\
Motivation (strong) & 2.57 & 1.25 & 3.89 & $<0.001$ \\
Appreciation (good) & 1.19 & -0.35 & 2.73 & 0.132 \\
Posbindu chairman leadership (good) & 1.73 & 0.44 & 3.03 & 0.009 \\
Social network support (strong) & 1.24 & 0.14 & 2.34 & 0.028 \\
Random effect & & & & \\
Posbindu & & & & \\
Var (Constanta) & 5.54 & 1.83 & 16.75 & \\
n observation = 200 & & & & \\
n Posbindu group= 25 & & & & \\
Log likelihood = -75.19 & & & & \\
LR test vs. logistic regression, $\mathrm{p}<0.001$ & & & & \\
ICC = 62.73\% & & &
\end{tabular}

\section{DISCUSSION}

1. The effect of training on the job performance

Cadres who had attended Posbindu training had a logodd (probability) to perform well 1.75 units higher than cadres who had never attended the training $(\mathrm{b}=1.75 ; 95 \% \mathrm{CI}=0.28$ to $3.22 ; \mathrm{p}=0.019$ ).

This is in accordance with a study conducted by Pangestuti et al. (2020), which stated that training has a significant effect on performance. Training is an organized activity to provide information or instructions to improve performance or increase knowledge and ability to achieve organizational goals. The training aims to increase motivation and self-confidence to do a job. With high motivation and self-confidence as well as good knowledge and abilities, performance will be even better (Walters and Rodriguez, 2017). The same thing was stated by Musoke et al. (2019). After participating in training, cadres have high motivation to do work and cadres experience increased competence and performance.

Training is a "software" that can affect motivation and performance. Training affects cadre performance by affecting self-confidence and attitudes. Having a high sense of self-confidence and a good attitude will encourage someone to have a good performance, too (Kok et al., 2017). Chung et al. (2017) highlighted the importance of the effect of training on cadre performance. Training should be carried out regularly, based on competence, and developed specifically according to the community's conditions. Routine training can help cadres apply knowledge in action to improve their performance as a cadre within a certain time.

\section{The effect of ability on performance} The statistical tests results showed cadres with good abilities had a logodd (probability) to perform well 2.50 units higher than cadres 
with less ability $(b=2.50 ; 95 \% \mathrm{CI}=0.95$ to 4.04; $\mathrm{p}=0.002$ ).

Hidayati et al. (2020) stated that ability is one factor that significantly affects cadre performance. Hastuti (2018) stated that cadres with good abilities would do a good job, not wait for leadership orders. The greater the ability you have, the greater the chance to complete the job correctly according to what has been determined (Kasmir, 2016).

Ability is a major factor that will affect work behavior and individual performance. Human resources play an important role in an organization. The quality of human resources is a key point that must be considered to achieve organizational goals. Cadre performance can be improved if it is accompanied by an increase in hard skills and soft skills. By paying attention to this, cadres can maximize performance according to the responsibilities given.

\section{The effect of tenure on performance} Cadres with tenure $\geq 1$ year had a logodd (probability) to perform well 1.99 units higher than cadres with less than one year of employment $(b=1.99 ; 95 \% \mathrm{CI}=0.05$ to 3.92 ; $\mathrm{p}=0.044)$.

Yuliani et al. (2019) stated a significant effect between the length of employment and cadre performance. The length of employment is identical to a person's experience and skills. Length of employment can affect knowledge. A long length of employment, coupled with continuous practice, will increase and improve one's skills. The work will be of higher quality and will be completed faster. A longer employment length as a cadre can improve cadres' abilities and skills (Afifa, 2019).

Kambarami et al. (2016) stated that the longer a person works, the more experience will be gained. Experience is knowledge or skills controlled by someone, which results from an act or job within a certain period. As experience increases, the ability to work will increase. Cadres with more work experience tend to have a more creative and innovative mindset in implementing various strategies to improve health services (Coatsworth et al., 2017). A longer tenure allows a person to have more opportunities to take part in training so that they can increase their knowledge and skills at work (Kawakatsu et al., 2015).

\section{The effect of motivation on perfor- mance}

Cadres with strong motivation had logodd (probability) to perform well 2.57 units higher than cadres with weak motivation $(\mathrm{b}=$ 2.57; 95\% $\mathrm{CI}=1.25$ to 3.89 ; $\mathrm{p}<0.001$ ).

Afifa (2019) stated that motivation is one of the dominant factors that affect cadre performance. The higher the motivation of the cadres, the better the performance. Based on Maslow's theory, individuals need selfactualization to become a better person. Cadres with high motivation need to fill their lives with positive things so that their lives are more meaningful. Motivation shapes the personality of the cadres to be more enthusiastic in carrying out their duties. High social enthusiasm motivates cadres to inspire, stimulate, mobilize and motivate people to participate in health programs. The altruistic spirit in cadres to empower themselves to be of benefit to many people is an encouragement to work optimally.

The motivation of cadres is driven by the desire to help the community through education about health, opportunities to gain knowledge and experience, and social responsibility for their role as cadres (Winn et al., 2018). In their study, Shipton et al. (2017) stated that one of the things that motivate cadres is pride in contributing to public health and moral responsibility to serve the community. With the strong motivation of cadres, it will encourage the sustainability of health programs in the community. 


\section{The effect of appreciation on performance}

Cadres with good appreciation have logodd (probability) to perform well 1.19 units higher than cadres with less appreciation. However, this was not statistically significant $(b=1.19$; $95 \% \mathrm{CI}=-0.35$ to 2.73 ; $\mathrm{p}=0.132$ ).

The results showed that the appreciation did not significantly affect the cadres' performance. Appreciation is not the main factor that motivates cadres to work. Giving appreciation is not the only element in cadre job satisfaction, but giving motivation from the leadership to cadres has a more important role (Nugraheni and Hartono, 2018).

Some cadres understand that their roles and duties as cadres are voluntary. Not all cadres work only hoping for an appreciation (Wirapuspita, 2013). The absence of a meaningful correlation between the giving appreciation and the cadres' performance was probably because the appreciation was given to all cadres, regardless of their performance. So, cadres with good or poor performance get the same thing.

\section{The effect of the leadership of the Posbindu chairman on performance} Cadres with good Posbindu chairman leadership have logodd (probability) to perform well 1.73 higher than cadres with poor Posbindu chairman leadership ( $b=1.73$; $95 \%$ $\mathrm{CI}=0.44$ to 3.03 ; $\mathrm{p}=0.009$ ).

Leadership is defined as the power to use and influence, inspire a person or group to achieve certain goals/objectives. Leaders play a very strategic role in deciding other organizations, groups or communities to achieve certain predetermined goals (Mulyadi, 2018). A good leader's behavior will make someone follow the orders given, and vice versa (Kashmir, 2016). Purba and Ginting (2019) stated that there is a leadership influence on cadre performance. Leadership has an important role in developing strategies to improve the performance of Pos- bindu cadres. The success of communitybased health programs needs to be supported by leadership empowerment. The role of leadership in community empowerment in the health sector is disseminating information, providing examples, raising awareness, motivating, guiding, mobilizing communities, facilitating and allocating resources (Sulaeman et al., 2015).

A leader must provide support and motivation to the cadres under himby assigning tasks that are always monitored, informing cadres of right and wrong things, always considering the cadres' abilities before giving assignments, giving appreciation and paying attention to the welfare of cadres (Sulaeman et al., 2016). Supriyatno (2017) stated that leadership has a significant influence on cadre performance. Leaders must be able to provide direction, solve problems, coordinate internally and externally, accept subordinates' opinions, and discuss and make breakthroughs in carrying out tasks. The relevant leadership applied in the cadre environment is democratic because problemsolving and decision making involves all cadres. Good leadership, which is motivational and open, is a factor that can provide satisfaction and, in the end, can affect the performance of Posbindu cadres.

\section{The effect of social network support on performance}

Cadres with strong social network support had logodd (probability) to perform well 1.24 units higher than cadres with weak social network support $(\mathrm{b}=1.24 ; 95 \% \mathrm{CI}=0.14$ to $2.34 ; \mathrm{p}=0.028$ ).

One of the important keys to community-based health programs' success is building networks (Nugraheni and Hartono, 2018). Kurniavie et al. (2020) stated that the support of social networks, especially the community and village government, greatly affects cadres' performance. Cadres with longer tenure are likely to be more able to 
improve social networks, have broader relationships, are more authoritative, and are more able to influence the community to be involved in health programs (Sulaeman et al., 2016). The longer the working period, the more familiar the cadres will be and build a strong social network to get community support. Cadres is the driving force for social support through community leaders. These community leaders can bridge the health sector as implementers of health programs and the community. Social support from community leaders is basically to socialize health programs so that people are willing to accept and participate in activities in Posbindu.

Support from the community will increase the cadres' motivation and enthusiasm so that performance will increase (Profita, 2018). Social network support is important for the continuity of Posbindu activities. Support from a strong social network will enhance partnerships to support innovations in Posbindu activities. Support from the government, especially the village government, is closely related to implementing activities, providing infrastructure, financial support, and so on, which greatly affects the performance of cadres.

\section{AUTHOR CONTRIBUTION}

Eka Siti Chasanah, as the main researcher, collected data, and conducted data analysis. Endang Sutisna Sulaeman provided input on the conceptual framework and material suggestions about cadres. Setyo Sri Rahardjo advised on study materials and writing techniques.

\section{CONFLICT OF INTEREST}

There is no conflict of interest in this study.

\section{FUNDING AND SPONSORSHIP}

The source of research funding comes from the budget of the Center for Quality Improve- ment of Health Human Resources, the Agency for Development and Empowerment of Human Resources for Health, Ministry of Health of the Republic of Indonesia.

\section{ACKNOWLEDGEMENT}

The authors would like to express their gratitude to the Ministry of Health, the Karanganyar District Health Office, the Head of the health centers in Karanganyar Regency, and the Posbindu cadres who helped this study.

\section{REFERENCE}

Afifa I (2019). The cadre performa in stunting prevention-rule of working duration as cadre, knowledge, and motivation. Jurnal Kedokteran Brawijaya. 30(4):336-341. http://dx.doi.org/10.21776/ub.jkb.2019.030.04.19.

Chung MHL, Hazmi H, Cheah WL (2017). Role performance of community health volunteers and its associated factors in Kuching district, Sarawak. J Environ Public Health. doi: 10.1155/2017/9610928.

Coatsworth K, Hurley J, Miller-Rosser K (2017). A phenomenological study of student nurses volunteering in Nepal: Have their experiences altered their understanding of nursing?. Collegian. 24(4): 339-344. doi: 10.1016/j.colegn.2016.07.003.

Hastuti D (2018). Pengaruh motivasi, kompetensi dan kepuasan terhadap kinerja kader kesehatan dengan komitmen kerja sebagai variabel intervening (Studi Puskesmas Pagiyanten Kabupaten Tegal).Jurnal Magisma. 6(1): 122.

Hidayati U, Tamtomo DG, Murti B (2020). Contextual effect of integrated health post on the community health personnel performance: a multilevel evidence from Purworejo, Central Java. J Health Policy Manage. 5(1): 1-12 doi:10.269- 
Chasanah et al./ Contextual Effect of the Integrated NCDs Health Post

11/thejhpm.2020.05.01.01.

Hastuti D (2018). Pengaruh motivasi, kompetensi dan kepuasan terhadap kinerja kader kesehatan dengan komitmen kerja sebagai variabel intervening (Studi Puskesmas Pagiyanten Kabupaten Tegal). Jurnal Magisma. 6(1): 122.

Hidayati U, Tamtomo DG, Murti B (2020). Contextual effect of integrated health post on the community health personnel performance: a multilevel evidence from Purworejo, Central Java. J Health Policy Manage. 5(1):1-12.doi:10.26911/thejhpm.2020.05.01.01

Jeet G, JS Thakur, Prinja S, Sigh M (2017). Community health worker for Non Communicable Disease prevention and control in developing countries: evidence and implycations. PLOS One. 12(7): e0180640. https://doi.org/10.1371/journal.pone.0180640.

Kambarami RA, Mbuya MNN, Pelletier D, Fundira D, Tavengwa NV, Stoltzfus RJ (2016). Factors associated with community health worker performance differ by task in a multi-tasked setting in rural Zimbabwe. Glob Health Sci Pract. 4(2): 238-250. http://dx.doi.org/10.9745/GHSP-D-16-00003.

Kawakatsu Y, Sugishita T, Tsutsui J, Oruenjo K, Wakhule S, Kibosia K, Honda S (2015). Individual and contextual factors associated with community health workers' performance in Nyanza Province, Kenya: A multilevel analysis. BMC Health Services Research. 15(1): 1-10.doi:10.1186/s12913-015-1117-4.

Kementerian Kesehatan RI.(2014). Pedoman Umum Pos Pembinaan Terpadu Penyakit Tidak Menular. Jakarta

Kementerian Kesehatan RI. (2014). Buku Pintar Posbindu PTM : Penyakit Tidak Menular dan Faktor Risiko. Jakarta Kementerian Kesehatan Republik Indonesia
(2018). Riset Kesehatan Dasar. https://www.persi.or.id/images/2017/litbang/riskesdas_launching.pdf.

Kementerian Kesehatan RI. Direktorat Jenderal Pencegahan dan Pengendalian Penyakit (2019). Petunjuk Teknis Pos Pembinaan Terpadu (Posbindu) bagi Kader. Jakarta

Kok MC, Broerse JEW, Theobald S, Ormel H, Dieleman M, Taegtmeyer M(2017). Performance of community health workers: situating their intermediary position within complex adaptive health systems. Hum Resour Health. 1-7. doi: 10.1186/s12960-017-0234-z.

Kundu MK, Hazra S, Pal D, Bhattacharya M (2018). A review on Noncommunicable Diseases (NCDs) burden, its socioeconomic impact and the strategies for prevention and control of NCDs in India. . Indian J. Public Health. 62(4) :302-304. doi:10.4103/ijph.IJPH_32416.

Kurniavie LE, Pawito P, Murti B (2020). The association between the integrated health post activity and the performance of community health workers in child growth and development care service in Karanganyar, Central Java.J Health Policy Manage. 5(1): 48-60. doi:10.26911/thejhpm.2020.05.01.05.

Musoke D, Ssemugabo C, Ndejjo R, Atusingwize E, Mukama T, Gibson L (2019). Strengthening the community health worker programme for health improvement through enhancing training, supervision and motivation in Wakiso district, Uganda. BMC Research Notes. BioMed Central. 12(1) : 1-5. doi: 10.1186/s13104-019-4851-6.

Nugraheni WP, Hartono RK (2018). Strategi Penguatan Program Posbindu Penyakit Tidak Menular Di Kota Bogor. Jurnal Ilmu Kesehatan Masyarakat. 9(3): 198206. doi: 10.26553/jikm.v9i3.312. 
Pangestuti R, Dewi YLR (2020). Contextual factors of posyandu on cadre performance in providing maternal and child health service in Surakarta, Central Java. J Matern Child Health. 5(1) :2734.

Purba SY, Ginting R (2019). Hubungan kepemimpinan dengan kinerja kader imunisasi dasar campak pada bayi di wilayah kerja Puskesmas Padang Bulan tahun 2019. Jurnal Kesehatan Masyarakat dan Gizi. https://doi.org/10.35451/jkg.v2i1.221.

Profita AC (2018). Beberapa faktor yang berhubungan dengan keaktifan kader posyandu di desa pengadegan kabupaten Banyumas. Jurnal Administrasi Kesehatan Indonesia. 6(2):68.doi: 10.20473/jaki.v6i2.2018.68-74.

Rusdiyanti I (2017). Faktor-faktor yang mempengaruhi keaktifan kunjungan pos pembinaan terpadu penyakit tidak menular di desa. Healthy-Mu Journal. 1(2).

Sari DWR, Savitri M (2018). Faktor-faktor yang berhubungan dengan pemanfaatan posbindu penyakit tidak menular (PTM) di wilayah kerja puskesmas kecamatan setiabudi kota jakarta selatan tahun 2018. Jurnal Kebijakan Kesehatan Indonesia. JKKI. 7(2):49-56. https : // doi.org/10.22146/jkki.36849 Shipton L, Zahidie A, Rabbani F (2017). Motivating and demotivating factors for community health workers engaged in maternal, newborn and child health programs in low and middle-income countries: A systematic review. J Coll Physic Sur Pakistan. 27(3):157165.

Sulaeman ES, Murti B, Waryana (2015). Peran kepemimpinan, modal sosial, akses informasi serta petugas dan fasilitator kesehatan dalam pemberdayaan masyarakat bidang kesehatan roles of leadership, social capital, information access as well as health duty and facilitator within Public empowerment. Kesehatan Masyarakat. 9(4): 353-361. Sulaeman ES, Reviono R, Setyowati A (2016). Modal Sosial Kader Kesehatan dan Kepemimpinan Tokoh Masyarakat dalam Penemuan Penderita Tuberkulosis. Yarsi Med J. 24(1):24-41.

Supriyatno H (2017). Faktor-Faktor Yang Mempengaruhi Kinerja Kader Posyandu Lansia. Jurnal Ilmiah Kesehatan. 1(1):91-98. doi:10.35952/jik.v6i2.99.

Walters K, Rodriguez J (2017). The importance of training and development in employee performance and evaluation. World Wide Journal of Multidisciplinary Research and Development. 10(3): 206-212.

Winn LK, Lesser A, Menya D, Baumgartner JN, Kirui JK, Saran I, O’Meara WP (2018). Motivation and satisfaction among community health workers administering rapid diagnostic tests for malaria in Western Kenya. J Global Health. 8(1). doi: 10.7189/jogh.08.010401.

Wirapuspita R (2013). Insentif dan kinerja kader posyandu. Jurnal Kesehatan Masyarakat. 9(1):58-65. http://journal.unnes.ac.id/nju/index.php/kemas

World Health Organization (2018) Noncommunicable diseases key facts. 8. doi:10.1080/0003681031000154918.

Yuliani I, Murti B, Sulaeman ES, Oepomo TD (2019). Path analysis on the determinants of health cadres ability in early detection and management of pregnancy risk factors in Sleman, Yogyakarta, Indonesia. J Health Policy Manage. 4(1): 47-58. doi: 10.26911/thejhpm.2019.04.01.06. 